\title{
UNIVERSITYOF
}

FORWARD

THINKING

WESTMINSTER用

WestminsterResearch

http://www.westminster.ac.uk/westminsterresearch

\section{The London 2012 cultural programme: A consideration of Olympic impacts and legacies for small creative organisations in east London \\ Pappalepore, I. and Duignan, Michael B.}

NOTICE: this is the authors' version of a work that was accepted for publication in Tourism Management. Changes resulting from the publishing process, such as peer review, editing, corrections, structural formatting, and other quality control mechanisms may not be reflected in this document. Changes may have been made to this work since it was submitted for publication. A definitive version was subsequently published in Tourism Management, 54, pp. 344-355.

The definitive version in Tourism Management is available online at:

https://dx.doi.org/10.1016/..tourman.2015.11.015

(C) 2015. This manuscript version is made available under the CC-BY-NC-ND 4.0 license http://creativecommons.org/licenses/by-nc-nd/4.0/

The WestminsterResearch online digital archive at the University of Westminster aims to make the research output of the University available to a wider audience. Copyright and Moral Rights remain with the authors and/or copyright owners.

Whilst further distribution of specific materials from within this archive is forbidden, you may freely distribute the URL of WestminsterResearch: ((http://westminsterresearch.wmin.ac.uk/).

In case of abuse or copyright appearing without permission e-mail repository@westminster.ac.uk 

Please reference this article as:

Pappalepore, I., \& Duignan, M. B. (2016). The London 2012 cultural programme: A consideration of Olympic impacts and legacies for small creative organisations in east London. Tourism Management, 54, 344-355.

This is the final (accepted) version of this paper. The published article can be accessed here http://www.sciencedirect.com/science/article/pii/S0261517715300492

The London 2012 cultural programme: A consideration of Olympic impacts and legacies for small creative organisations in east London.

Ilaria Pappalepore ${ }^{\mathrm{a}}$ (corresponding author)

(a) University of Westminster, 35 Marylebone Road, London NW1 5LS, UK i.Pappalepore@westminster.ac.uk

Tel. +44(0)2035066657

Michael Duignan ${ }^{\mathrm{B}}$

(b) Anglia Ruskin University, East Road, Cambridge CB1 1PT, UK michael.duignan@anglia.ac.uk

\begin{abstract}
This study investigates the impacts of the London 2012 Olympic Games and their related cultural programme on local small creative organisations in East London. It contributes to unpacking the elusive concept of legacy thorough an in-depth analysis of creative organisations' stories and experiences, combined with an analysis of policy documents and interviews with key informants, over a four-year period (2010-2014). A range of potential impacts of mega-events for creative organisations are identified and systematically discussed. The results highlight a gap between
\end{abstract}


Olympic rhetoric and local reality. Problems include inadequate local consultation, barriers to accessing opportunities and inability to leverage effectively. The study also explores the role of cultural tourism in delivering an Olympic legacy for the local creative industry. It finds that opportunities to showcase deprived - but creative - areas in East London, and foster the development of creative forms of tourism, were missed.

Keywords: Cultural Olympiad; London 2012; Event Tourism; Creative industry; Olympic Games.

\section{INTRODUCTION}

Thanks to their global presence, ability to mobilise considerable public funding and immovable pressured deadlines for completion, mega-events are widely regarded as a powerful way to catalyse development policies (Burbank et al., 2002). Sought-after impacts include employment opportunities, local business development and the creation of infrastructure that can support longerterm development for host regions (e.g. Chalip \& Leyns, 2002). However, as mega-event agendas have become increasingly ambitious in scope the complexity and costs of delivering such projects have grown exponentially. This requires policy-makers to pursue a range of positive urban impacts and legacies under close public scrutiny. Given the potential gaps between Olympic rhetoric and reality, it is unsurprising that critics refer to such interventions as placebos (Rojek, 2014) which divert attention and resources away from fundamental social problems.

In the case of the London 2012 Olympic and Paralympic Games (hereafter London 2012), regenerating the deprived East End, enhancing the lives of its local people and attracting people to the area were presented as key objectives (DCMS, 2008; House of Lords, 2013). However, research demonstrates that event-led regeneration projects can lead to marginalising local host communities (e.g. Vigor et al., 2004). Raco \& Tunney (2010) claim that such projects often view local areas as 'blank slates' (2010: 2087) available for wholesale redevelopment. Local small business communities in unappealing, low-cost neighbourhoods are discarded as firms in inevitable economic decline, and seen as uncompetitive and old-fashioned (Imrie \& Thomas, 1995). The extent to which local business communities can effectively adapt, thrive and survive across the disrupted environments such events create is questionable. It is therefore of great importance to assess the local impacts bestowed upon these stakeholders. The present research aims to investigate these issues by exploring the impacts of London 2012 and its related cultural programme on local small creative organisations in East London. These organisations are often the most vulnerable in 
times of change but contribute significantly to creative innovation and cultural diversity (Jacobs, 1969).

In the development of this study, it was not assumed that such impacts could - or should be expected to - occur. However, we believe that small creative and cultural organisations face great challenges and opportunities during sport and cultural mega-events, and a gap in existing research should be addressed. Furthermore, this research is particularly relevant in the case of London 2012 because: (1) East London hosts a high density of micro and small creative organisations; (2) the creative and cultural sectors were expected to be key beneficiaries of the Olympic Games (DCMS, 2007a; 2008; 2014); (3) the four-year cultural programme and the London 2012 festival were key elements of London 2012; (4) London hoped to showcase the city as a 'creative and welcoming city' (Mayor of London, 2007: 5); and (5) given the wider, strategic importance of the creative sector for promoting national, city-wide and local economic vitality (Work Foundation, 2010; House of Lords, 2013; DCMS, 2014).

In spite of its central role in mega-event policy and academic literature, the concept of 'legacy' still remains largely unexplored and fraught with ambiguity. According to the International Olympic Committee (IOC), legacy refers to impacts which are both positive and long term (IOC, 2013). Similarly, Gold and Gold (2008) note that the concept is usually associated with the intergenerational benefits of mega-events, which will allegedly repay the costs borne by present citizens by benefitting future generations. A small number of authors (for example Preuss, 2007) have attempted to dissect the term, however to date a widely accepted conceptualisation of legacy is still missing. One of the aims of the present paper is therefore to contribute to the understanding of this elusive concept by focusing on a specific type of stakeholder, namely small creative and cultural organisations.

\section{A LEGACY FOR LOCAL CREATIVE ORGANISATIONS?}

Local business opportunities and developing local talent are often identified as positive wider legacies of major cultural and sporting events (Sacco \& Tavano Blessi, 2007; Smith, 2012). Therefore, it is perhaps surprising that local governments rarely monitor the impacts of such events on local creative and cultural organisations (Richards \& Palmer, 2010). Recently, however, increased recognition of the creative industry's importance in local economies and a wider 'creative turn' in the social sciences and policy-making (Richards, 2011) have triggered growing attention 
from academic researchers towards the legacies of major events for this sector. A review of existing research on this topic, which formed the basis for our analysis, is summarised in Table 1.

Research in this area has identified a number of potential positive impacts of major cultural events on creative organisations, including improved visibility, development of new ideas and increased collaborations (see Table 1). However, the global ambitions of major events mean that related festivals and cultural programmes tend to prioritise spectacular, flagship cultural products over locally rooted ones (García, 2004). Whilst this may help local cultural organisations to gain international exposure and draw media attention, local people may feel the event programme bypasses the kind of culture they appreciate (O'Callaghan \& Linehan, 2007). Another potential positive impact of major events for creative organisations is the opportunity to benefit from additional grants linked to specific projects (Low \& Hall, 2011). However, in the case of megaevents, funding is often diverted from the arts to pay for mega-event infrastructure. In the case of London 2012, for example, the main distributor of public grants for the arts in England (Arts Council England) was obliged to contribute a total of $£ 112.5$ million to the Olympic Distribution Fund (ACE, 2012).

In spite of small businesses' importance in these events' success (Osmond, 2002), little evidence exists that small businesses have ever significantly influenced the objectives of mega-events (Flyvbjerg et al., 2003). Before these events, the support of small businesses and other local communities is pursued to seek legitimation of policy objectives (Foley et al., 2012). However, such stakeholders are often unable to obtain action in response to their concerns, in accordance with the 'principle of who or what really counts' (Mitchell et al., 1997: 853). Local small creative organisations have 'legitimacy of claim' in the context of a mega-event because their interests are at risk; however, they are unlikely to have the power to carry out their will in the face of resistance (Weber, 1947). As a result, they lack the authority (defined as a combination of legitimacy and power) and salience (legitimacy, power and urgency) to bring about the outcomes they desire, such as being directly involved in the official cultural programme or benefitting from tourist footfall.

As a result, the inclusion of arts communities is frequently encouraged at the bidding stage, before quickly turning into marginalization as the project becomes real (Gilmore, 2014). Consequently, in order to be sustainable, major events should redistribute benefits to stakeholders and simultaneously meet the needs of the host community through inclusive, bottom-up leveraging strategies (Ziakas,

\footnotetext{
${ }^{1}$ In return, the lottery distributors who contributed to the Olympic Distribution Fund will receive a share of the capital receipts from the sale of the Olympic Village. According to the Arts Council, their share is expected to be circa $£ 20.9 \mathrm{~m}$ (personal communication).
} 
2014). Leveraging, or the planned creation of positive legacies for host communities (as opposed to mere post-event evaluation of impacts), should be viewed as a tool with which to 'enable positive social change, rectify power imbalances and decrease inequalities' (Ziakas, 2014: 9).

However, many small businesses fail to benefit from major events precisely because they lack the skills or resources to leverage effectively (Chalip \& Leyns, 2002). In this sense, creative organisations have an advantage: being able to use their creativity to maximise limited resources and appeal to potential customers (Fillis, 2009). Low and Hall (2011) argue that cultural organisations are active agents - rather than passive recipients - of mega-event impacts. O'Brien (2006) describes a successful government attempt to help local businesses benefit from a megaevent (the Sydney 2000 Olympic Games) through early development of a pioneer networking-based event-leveraging programme. Sadly, the intense time pressures experienced by delivery authorities ahead of mega-events often leave little scope for such projects, and provide justification for overriding local concerns and avoiding stakeholder consultation (Hiller, 2002). Therefore, they may fail to recognise the types of close-knit networks, socio-economic and qualitative interdependencies local traders rely on for competitiveness and survival (Raco \& Tunney, 2010). 
Table 1 - List of key potential impacts of major events on creative organisations as identified by relevant literature. The positive/longer term quadrant represents event legacy according to the IOC's definition of legacy (IOC, 2013).

\begin{tabular}{|c|c|c|}
\hline Legacy & POSITIVE & NEGATIVE \\
\hline 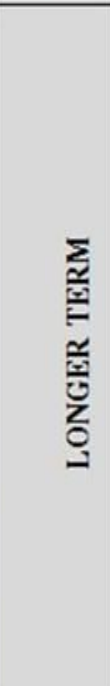 & $\begin{array}{l}\text { - Development of local talent (Sacco \& Tavano Bles si, 2007) } \\
\text { - Improvement of local creative industry's profile and credibility (Impacts 08, 2009) } \\
\text { - Better production organis stion (Bergs gardet al., 2010) } \\
\text { - Development of stable learning circuits (Paiola, 2008) } \\
\text { - Strengthening of ties and interaction between organisations (SchüBler \& Sydow, } \\
2013 \text { ); } \\
\text { - Increased cohesion (Paiola, 2008), collaborations and partnerships (Bergs gardet } \\
\text { al., 2010; Bergs gard \& Vassenden, 2011) } \\
\text { - Increased busines s confidence (Dwyer et al., 2000) } \\
\text { - Enhanced business contacts (Dwyer et al., 2000) } \\
\text { - Increased expenditure by intemational tourists after the event (DCMS, 2007b) } \\
\text { - Development of cultural infrastructure (A shton, 2012) } \\
\text { - Development of creative clusters/cultural quarters (Gospodini, 2009) } \\
\text { - Development of niche forms of tourism (Stevens on, 2012) }\end{array}$ & $\begin{array}{l}\text { Displacement of local businesses (Raco \& Tunney, } \\
\text { 2010) } \\
\text { - Increased renting costs due to gentrification (McKay \& } \\
\text { Plumb, 2001; Kavetsos, 2012) }\end{array}$ \\
\hline $\begin{array}{l}\frac{\sum}{0} \\
\frac{1}{2} \\
\frac{0}{0} \\
\frac{0}{0} \\
\frac{0}{0}\end{array}$ & $\begin{array}{l}\text { - Visitor increase (Garcia, 2008) } \\
\text { - Development of new ideas (Bergsgard et al., 2010); Exchanges of ideas (Dwyer et } \\
\text { al., 2000) } \\
\text { - Encouragement of first-time relationships between gras sroots groups and } \\
\text { mainstream organisations (Garcia, 2004) } \\
\text { - Increased vis ibility, international expo sure (Paiola, 200 \&; Low \& Hall, 2011) } \\
\text { - Development of innovative connections with local audiences (Low \& Hall, 2011) } \\
\text { - Additional funding such as public grants (Low \& Hall, 2011) and sponsor ship } \\
\text { contracts (Garcia, 2008) } \\
\text { - Trade opportunities directly related to the event, such as providing music, } \\
\text { performances, lighting or sound (Chalip \& Leyns, 2002; Low \& Hall, 2011; Hiller, } \\
\text { 2006) } \\
\text { - Business development (Dwyer et al., 2000) }\end{array}$ & $\begin{array}{l}\text { - Diversion of funding from the arts to fund mega-event } \\
\text { infrastructure (Kenyon \& Palmer, 2009) } \\
\text { - Reduced footfall (French \& Disher, 1997; House of } \\
\text { Lords, 2012) } \\
\text { - Commodification of cultural products (Garcia, 2008) } \\
\text { - Marginalisation of cultural min orities; mainstream } \\
\text { culture and 'high arts' prioritised (O' Callaghan \& } \\
\text { Linehan, 2007; Garcia, 2008) } \\
\text { - Effect on regular residents avoiding hosting areas (local } \\
\text { aversion markets) (Spilling, 1996) }\end{array}$ \\
\hline
\end{tabular}

\section{TOURISM, MAJOR EVENTS AND THE CREATIVE INDUSTRY}

In cultural events, the local community, tourists and creative organisations collaboratively create participants' experiences. Cultural events have therefore increasingly drawn researchers' attention for their role in developing connections between places and communities, and between creativity and tourism (Richards, 2011). Intuitively, creative and cultural organisations should benefit from event-induced tourism in various ways, including increased demand for cultural products, footfall and visibility for their businesses. Nonetheless - as discussed in the next paragraphs - the relationship between event tourism and creative industries is controversial.

Mega-events have been associated with developing iconic architecture, cultural infrastructure and cultural quarters, all of which could help attract the type of tourist who contributes to the local creative economy. The $\$ 40 \mathrm{bn}$ Olympic budget for Beijing 2008 included funding to develop a 
museums network, an ambitious heritage renovation programme and the creation of new cultural facilities (Ashton, 2012). Similarly, the London 2012 Olympic Park development in Stratford involved constructing an iconic sculpture (ArcelorMittal Orbit), as well as outdoor and indoor event space, a theatre, a cinema and extensive green areas featuring outdoor art. Projects are currently under way to develop a large cultural centre that will host a museum and university campus in the former Olympic Park (BBC, 2014). These projects are part of a wider cultural legacy strategy for the Olympic Park 'centred around developing east London as a creative destination with an international reputation' (London Legacy Development Corporation [LLDC], 2014: 34). Such attempts to use mega-events to trigger the development of cultural quarters in cities are not new. The 2004 Athens Olympics also involved developing creative and leisure clusters. However, in Athens, spontaneous clusters have thrived, whereas those planned as part of the Olympic project became 'deserted islands' after the Games (Gospodini, 2009).

Cultural projects, such as the Cultural Olympiad, local festivals and other activities linked to the Games, may attract cultural tourists before and during the main sports programme. In fact, García (2004) describes cultural programmes as mechanisms mainly for attracting media attention and tourism. The Games spectacle itself represents an opportunity for creative organisations to gain exposure and market themselves to tourists (Low \& Hall, 2011). However, tourism development is not necessarily welcomed by creative communities. Molotch and Treskon (2009: 529) describe how tourists are perceived by art galleries in Soho, New York: 'besides not buying, the tourists go into the galleries (and) laugh at the art'. Also, artists associate tourism development with gentrification. The staging of mega-events in particular is demonstrably a major cause of rising residential property prices in host areas (McKay \& Plumb, 2001; Kavetsos, 2012). Often, Olympic park construction also leads to business displacement as a result of compulsory purchase orders. In London, for example, more than 200 local small- and medium-sized businesses were displaced to allow the Olympic Park's construction (Raco \& Tunney, 2010).

Mega-events such as the Olympic Games and FIFA World Cups are believed to intensify local leisure consumption, providing trade opportunities for the local retail, cultural, leisure and hospitality industries (Hiller, 2006; Chalip \& Leyns, 2002). However, these claims are not always supported by evidence. Research into the 1996 Atlanta Olympic Games, for example, found that most hospitality and retail businesses experienced slower than normal business during the Games (French \& Disher, 1997). Similarly, Central London reported a negative effect on retail and a drop of up to $60 \%$ in tourist visits to some visitor attractions during the 2012 Olympic Games (House of Lords, 2012). Such problems are associated with a unique territorialisation of the Olympic Games, 
characterised by spatial segregation of event zones, intensified security and appropriation of public spaces (Smith, 2014). Increased fear of terrorism, coupled with the need to run such a complex event efficiently, provides legal and moral justification for the development of an 'Olympic state of exception' (Marrero-Guillamón, 2013), a condition characterised by war-like exceptions to the legal, policing and security systems.

McGillivray and Frew (2014) correctly note that Olympic territorialisation is physical as well as symbolic in that zoning contributes to directing the gaze of spectators towards the logos and commercial offerings of official sponsors. Drawing upon Deleuze and Guattari's conceptualisations (1988), McGillivray and Frew (2014) describe Olympic sites as 'striated' spaces: static, stateenforced, functional and corporate-dominated. By contrast, they note, smooth spaces such as spontaneous pop-up events and artists' occupations of space close to Olympic zones 'are the site of de-territorialising creative resistance and escape' (p. 7). This understanding of Deleuze and Guattari's work is particularly relevant to the present study, and consistent with previous interpretations (e.g. Deleuze, 1995; O'Sullivan, 2006) which have highlighted the role of artistic movements as creators of smooth space or - using Deleuze and Guattari's terminology - as a 'war machine'.

Despite a perhaps disappointing body of evidence, tourism legacy is often used as a primary justification for staging mega-events (Smith \& Stevenson, 2009). Olympic advocates postulate that image enhancement obtained by a host region from hosting a successful mega-event should be used as measure of tourism legacy rather than the actual number of tourists during the event. Critics, on the other hand, claim that the increasing importance of image and marketing objectives has led to a form of cultural capitalism (Rifkin; 2000). Rojek (2013: 41), for example, uses the term 'event appropriation' to identify 'the seizure, by external or contingent interests, of the goodwill and spirit of escapism and transcendence that is attached to Global Events'. Host cities' increasing funding needs, associated with inter-urban competition, also mean that the desires of corporations, particularly sponsors, must be accommodated in the event agenda (Tomlinson, 2005) leading to commodification of the cultural product. Crucially, McGuigan (2005) proposes a distinction between sponsorship as we know it - the association of a brand with a cultural product, for example an event - and the more insidious concept of 'deep sponsorship'. The latter, an emblematic product of neoliberal policy and its offspring the public-private partnership, is 'the actual constitution of the cultural object itself in pursuit of corporate goals' (p. 235).

According to Harvey (1989a), urban entrepreneurialism, associated with deindustrialisation and the dominant ideology of neoliberal globalisation, has led to the transformation of society into a 
gigantic, risk-taking marketplace. In such a capital system public institutions are driven by market principles and funds are redistributed away from local service provision towards more speculative (as opposed to rationally planned) projects. Temporal urban spectacles also play a social control role as they foster civic pride and, like a carnival mask, enable the disguising of unresolved socioeconomic problems and the increasing alienation brought about by modern life (Harvey, 1989b; 1989a). Referring to event-led regeneration and to the famous Roman bread and circuses formula, Harvey notes: 'the circus succeeds even if the bread is lacking. The triumph of image over substance is complete' (1989a: 14).

\section{CASE STUDY: East London and the London 2012 Cultural Programme}

London's East End has a complex history characterised by both significant inward migration and de-industrialisation following the closure of key manufacturing and dockland operations in the midlate $20^{\text {th }}$ century. Since the $1980 \mathrm{~s}$ the East End has thus been central to many of London's regeneration strategies; at the beginning of the $21^{\text {st }}$ century East London was still in the top $10 \%$ of deprived areas in the UK (Government Office for London, 2007). Given the existing high levels of deprivation, a vision for London 2012 to be 'the catalyst for one of the biggest and most ambitious transformation projects in Europe' (DCMS, 2012: 42) played a pivotal role in securing London's bid for the 2012 Games (Institute for Government, 2013). Creative industries were deemed significantly important in such development, particularly as the East End hosts a high density of micro and small creative businesses within the key Olympic boroughs. Alongside the technology and financial sectors, creative industries are deemed to be key for driving the city's growth over the next five years (KPMG, 2014). It is therefore very important to look at how London 2012 impacted on this key sector.

The Games' cultural programme was a key aspect of the successful Olympic bid. According to Arts Council England, 40,464 artists were involved with the Cultural Olympiad. Of these, 6,160 were emerging artists (ACE, 2013). According to a tradition started with Barcelona 1992, the official Cultural Olympiad programme for London 2012 started four years ahead, in 2008. Unprecedentedly, however, projects and events took place on a national scale. 13 creative programmers across the UK were responsible for fostering and supporting ideas at the local level (ACE, 2013). The Cultural Olympiad's finale (the London 2012 Festival) took place in London between June and September 2012. An evaluation report produced by the main funding distributor 
for the cultural programme (Legacy Trust, 2013) claims the programme's success in combining artistic quality and community participation, thus ensuring a lasting positive cultural legacy on local cultural organisations and communities. In response to strict copyright restrictions on Olympic logos and trademarks, the 'Inspired by 2012' project was also created. This project allowed successful cultural organisations to benefit from association with the Games without using the Olympic logo by adopting the Inspired mark.

Live sites for watching the Games with outdoor screenings and performance spaces, alongside Torch Relay events right through to the opening and closing ceremonies, also formed key opportunities for local creative organisations according to Voluntary Arts (2008). The 'Cultural Diary', an online medium for agglomerating both London-centric and nation-wide key cultural events, provided a key gateway for aggregated access. London 2012 also inspired a number of locally focused special events. For example, 'Carnivals' and the 'Wick Festivals' in and around Hackney (see Stevenson, 2012). 'Create' formed a key part of the cultural legacy programme for London 2012 (DCMS, 2014). Launching in 2008, Create was an annual festival across the six Olympic boroughs designed to engage with the local creative sector in the run-up to the Games. It comprised a wide range of cultural projects, events, art installations and workshops, with the key vision including sustainability, up-skilling and building local capacity to ensure the festival would out-live the Olympics (Stevenson, 2012). Besides opportunities associated with direct participation in the cultural programme, it should be noted that an event of such scale also presents opportunities for creative organisations to supply services such as, for example, printing, graphic design, props, sound, and lighting design. What we can therefore deduce is that potential for showcasing both local and national talent through a medley of geographically dispersed projects existed within what we will hereafter refer to as London 2012's 'cultural programme'.

\section{METHOD}

Very few studies have attempted to provide an in-depth exploration of event impacts from a small creative organization's perspective. Therefore, this research is very exploratory in nature. As MacRury and Poynter (2009) note, it is vital to capture the narratives associated with specific host cities in order to understand the full legacy context. Therefore, a case study research strategy based on a specific mega-event (London 2012) and a specific geographic area (East London) was chosen.

The following research questions guided the study: 
1) What are the impacts - positive or negative, long or short term - experienced by small creative organisations in East London as a result of the 2012 Olympic Games and their related cultural programme?

2) What is the role of Games-driven tourism in delivering such impacts for small creative businesses in East London (if any)?

3) Can we identify any emerging legacies for East London's host community of small creative organisations?

The chosen method combined secondary research, qualitative questionnaires and semi-structured interviews. Furthermore, a separate systematic analysis of key documents released by both national and city level project actors is incorporated ${ }^{2}$. Primary data were collected between 2010 and 2014. Only micro and small creative organisations (as defined by DCMS, 1998 and European Commission, 2005) located in East London were included. This included small creative and cultural businesses (e.g. artists, design studios, dance companies, art galleries) as well as some non for profit organisations (e.g. small museums, charitable cultural organisations). There were five rounds of data collection during the 4-year research period:

- In 2010, a qualitative questionnaire was distributed by email to 460 creative organisations in East London. This sample was selected according to postcode following an extensive internet search. 64 organisations responded. The questions focused on expectations, engagement with and the impact of the Cultural Olympiad (which started in 2008), and awareness of opportunities linked to the Games and their cultural programme. The qualitative questionnaire was followed by 7 face-to-face interviews with 8 creative practitioners. The interviews aimed to discuss the issues and themes raised in the questionnaire in more detail. Interview participants were purposively selected based on questionnaire responses so as to achieve a mix of different perspectives and experiences.

- In 2012 (after the Games) another qualitative questionnaire (open questions) was distributed by email to 753 creative organisations in East London. The high mobility of small (particularly micro) creative organisations in London explains the partly different 2012 sample. As in the previous questionnaire, responses from organisations which did not meet the definition of a small creative organisation were discarded. As a consequence, 28 valid

\footnotetext{
${ }^{2}$ These include policy documents dated between 2004 and 2014 and produced by the DCMS, Government Office for London, Greater London Authority, House of Lords, London Assembly, London Development Agency, Olympic Delivery Authority, UK Government, Legacy Trust UK and Mayor of London (a full list of documents consulted is available from the authors).
} 
questionnaires were collected. The low response rate for the second questionnaire represents a limitation of this research. However, given the richness of the data obtained and the qualitative nature of the study, the sample was considered valid in accordance with the interpretive perspective adopted (Maxwell, 1992). The combination of multiple sources and methods together to construct arguments enhances what Yin (2003) refers to as 'construct validity'. The questions focused on the impacts of the Olympic Games and the cultural programme on their organisation. Then, twelve interviews were conducted in 2013 with thirteen creative practitioners in East London (with questionnaire respondents who were willing to take part). One respondent took part in both questionnaires (2010 and 2012) and an interview, while two answered the two questionnaires but did not take part in an interview.

- In 2014, four interviews were conducted with policy-makers and other key informants involved with local creative industries and/or Olympic Games delivery. These key informants were selected using a snowballing technique. A list of all interviewees is provided in Table 2.

The interviews were transcribed verbatim and all the qualitative data was analysed by the two researchers (also the authors of this article) using an established qualitative analysis technique (adapted from Yin, 2003). 'Investigator triangulation' was undertaken to ensure credibility of interpretation (Easterby-Smith et al., 1991) and enhance descriptive validity (Maxwell, 1992). The two researchers analysed the same data separately and then identified themes were compared and discussed. A final list of themes and sub-themes was agreed.

Table 2 - List of interviewees

\begin{tabular}{|l|l|l|}
\hline & $\begin{array}{l}\text { YEAR of } \\
\text { interview }\end{array}$ & Role \\
\hline 1. & 2010 & Ceramicist \\
\hline 2. & 2010 & Furniture Designer and producer \\
\hline 3. & 2010 & $\begin{array}{l}\text { Manager of cultural association and exhibition } \\
\text { space }\end{array}$ \\
\hline 4. & 2010 & Director of Cultural organisation and museum \\
\hline 5. & 2010 & $\begin{array}{l}\text { Co-director of gallery space for students and } \\
\text { graduate artists }\end{array}$ \\
\hline 6. & 2010 & Manager, museum \\
\hline 7. & 2010 & Executive director of community theatre A \\
\hline 8. & 2010 & Associate Producer of community theatre A \\
\hline 9. & 2013 & Director of design and printing company \\
\hline 10. & 2013 & Director of arts and cultural organisation \\
\hline
\end{tabular}




\begin{tabular}{|l|l|l|}
\hline 11. & 2013 & Artist \\
\hline 12. & 2013 & Manager, artists run gallery A \\
\hline 13. & 2013 & Artist and artist studio space manager \\
\hline 14. & 2013 & Ceramicist \\
\hline 15. & 2013 & Director, artists' run gallery B \\
\hline 16. & 2013 & Public art organisation \\
\hline 17. & 2013 & Manager, non-for profit artists run gallery C \\
\hline 18. & 2013 & Manager, non-for profit artists run gallery C \\
\hline 19. & 2013 & Graphic Designer \\
\hline 20. & 2013 & Art prints retail \\
\hline 21. & 2014 & Cultural Policy Consultant \\
\hline 22. & 2014 & Senior Manager, London Assembly \\
\hline 23. & 2014 & $\begin{array}{l}\text { Executive Director, London Legacy } \\
\text { Development Company }\end{array}$ \\
\hline 24. & 2014 & $\begin{array}{l}\text { Senior Manager, London 2012 Forum (official } \\
\text { local engagement body set up by the London } \\
\text { Organising Committee of the Olympic and } \\
\text { Paralympic Games, LOCOG) }\end{array}$ \\
\hline & & \multicolumn{2}{l}{} \\
\hline
\end{tabular}

\section{RESULTS}

\subsection{Expectations}

According to a report produced at bidding stage, six million visitors were expected in the six host boroughs over the three-month Olympic period, bringing opportunities for 'employment and training in creative, cultural, technical, support activities' and 'increased capacity for cultural production and tourism' (Powell, 2004: 2). As soon as the Olympic bid's success was announced in 2005, SPACE, an artists' support agency located in Hackney (one of the Olympic boroughs), established Legacy Now, an annual symposium aimed at discussing and raising awareness on issues related to the impact of London 2012 on creative organisations in Hackney.

Some of the creative practitioners who took part in this research in 2010 hoped that the cultural programme would increase 'networking, sharing of knowledge and creative exchange' (questionnaire, 2010). Some felt that they might benefit from 'the huge influx of people', as well as from additional funding and support for creative projects. Expectations with regard to opportunities for creative organisations linked to the Games were high:

'The joy throughout London when London won the Games, you know, it was palpable (...) And, you know, the thought of this wonderful thing, you know this big thing, and they just... businesses wanted to get involved' (interviewee 19). 
Organisations based near the Olympic Park in Stratford saw opportunities linked to the park (such as the development of art installations, local cultural events etc.) and to the area's regeneration prospects. One interviewee noted that, according to the UK media:

'there was going to be all sorts of events, that [artists] would be included in them, that people were going to be encouraged to come to the area, and there would be lots of coverage for the galleries' (interviewee 12).

However, creative organisations' perceptions of impacts changed drastically over time. As a result, the theme of 'disappointment' was prominent and consistent throughout the questionnaire responses and interviews conducted after the Games. A cultural policy consultant who was involved in local creative business consultations ahead of the cultural programme expressed his own disappointment upon realising that the cultural programme's centrality in relation to the Olympic offering 'clearly changed between 2006 and 2012; there were big dreams at the beginning and they were scaled right down' (interviewee 21).

\subsection{Leveraging}

Despite the generally high expectations with regard to potential impacts, only some research participants undertook any leveraging initiatives. Strict IOC rules on Olympic Games copyright constituted a barrier to leveraging according to some. A ceramic artist described her unsuccessful attempt to leverage the mega-event by opening a pop-up shop near the Olympic Park: 'few people came in, I mean there was kind of drips and drabs, but it was, it was noticeably quiet' (interviewee 14). In one case, the artists' disapproval of the Cultural Olympiad inspired an art exhibition and an 'anti-Olympics poster competition': 'it was anti Cultural Olympiad specifically because we were presenting culture that we thought was more valuable (...) in a sense, that was an inspiration, even if it was a negative thing' (interviewee 17). A few others mentioned leveraging initiatives such as developing Olympic-themed products or running an open studio event, a market stall or a local festival.

According to some respondents, leveraging was meaningless because the Olympic Games were never going to benefit small creative organisations anyway: 'I didn't think it was going to affect me at all. (...) well I couldn't see how it would' (interviewee 11). This reflected a belief among several respondents, that any available public grants or work opportunities connected to the cultural programme would only 'be allocated to large and long-established organisations, at the exclusion of smaller, innovative companies' (questionnaire, 2010). This opinion was expressed in 2010 and confirmed by the follow-up data collection in 2012-13. Respondents associated this 
problem with a number of factors. Firstly, the cultural programme curators' preference for internationally renowned cultural companies and artists, as discussed later. Secondly, the realisation that, in a very competitive environment characterised by strict health and safety and project delivery deadline requirements, many small companies could not 'present themselves as solidly as they needed to' (interviewee 21). Thirdly, many found CompeteFor, the supply-chain procurement system in place for the Games, inadequate for micro and small organisations and particularly for the cultural sector. Participants also found that lead times for applying for cultural programme projects were too long and the process too complicated for small organisations.

A senior manager of the London 2012 Forum confirmed this view

'with respect to the wider procurement for the Games, including CompeteFor - there are a couple of success stories for construction companies, but by and large it is not a great full picture for local businesses involved in this process" (interviewee 24).

\subsection{Communication}

Generally, research participants seemed to have very little knowledge of what the cultural programme entailed and the opportunities available for small creative organisations linked to London 2012. A very strong theme throughout the study was the lack of information and communication between creative organisations and event delivery and funding bodies. There was very little clarity about which organisations might function as intermediaries between small organisations and the Games' (including the cultural programme) delivery organisations. A few respondents mentioned intermediaries which, in their experience, played an important role in providing information and support, especially at an early stage. These were Create, CIDA (Creative Industries Development Agency) and ELBP (East London Business Place).

A similar role was played - although less successfully - by the six London boroughs, particularly Hackney and Tower Hamlets, who mainly communicated on practical issues such as road closures and branding (copyright) restrictions. Those respondents who attended Olympics-related public meetings noted that such occasions aimed to give information rather than listen. Even early meetings, labelled as consultation meetings, failed in their objective of creating a dialogue. For example, one interviewee said:

'[public meetings] were just kind of long, and told lots of practicalities and stuff; I mean it was all good (...) but I just, I don't think there was a great deal of opportunity for them to 
listen to us as well or... you know, they had so much going on that they didn't really... I felt like there was a resistance to the Hackney Wick community' (interviewee 14).

\subsection{Experiences of impact}

Of all the 89 creative organisations involved, $6 \mathrm{had}$, at the time of the research, obtained work or funding due to the Games and cultural programme. A further 5 respondents had unsuccessfully applied for funding. Those who had obtained work or funding mentioned some positive impacts of working for the Games or cultural programme for their organisation, beyond additional income. These included having a catalyst for establishing new projects, being able to plan projects further ahead, being able to work with larger, established organisations and developing new industry contacts. Also, a few of those who did not directly work for the cultural programme or Games delivery stressed some Olympic-related positive impacts, for example the development of a 'buzz' in East London during the pre-Olympic period and increased media focus on the cultural sector (the latter statement, however, was opposed by other respondents). One noted that even being only shortlisted for a large project allowed them to 'lever relations with some world-class artists'.

Many more respondents, however, described a complete lack of positive impacts, while stressing a number of negative ones. Most notably, these included a lack of funding for cultural projects, which they associated with public funding for the arts being diverted to pay for the Games, and increasing property prices, which they associated with Games-led gentrification. For example, an artist and gallery owner took part in the questionnaire in 2010, expressing positive views on the potential benefits of the Games for artists in East London. When she took part in the questionnaire again in 2012 and undertook an interview one year later, she revealed that the only real impact the Games had on her business was forcing her to close her gallery due to a fivefold rent increase.

\subsection{Tourism}

Besides benefitting directly from working for the event programme itself, according to much academic literature small creative organisations may also gain advantage from the event indirectly, most notably from event-led tourism. However, tourism during the main three-week sporting events period was particularly disappointing to respondents. This was, in the respondents' opinion, caused by four main factors: 'Boris Johnson's announcement [which] told everyone to stay away' (questionnaire, 2012), parking restrictions, tourists being marshalled between train stations and sports venues, and the nature of event tourists. These factors are discussed below. 
Despite initial claims that London would be 'big enough for all potential visitors' and 'open for business' during the Games (DCMS, 2007b), in preceding weeks London's mayor, Boris Johnson, ran a campaign inviting people not attending the sporting events to avoid Central London and the Olympic zones unless strictly necessary. This initiative (motivated by worries related to transport system capacity) caused a noticeable footfall reduction:

'We held an art market on the first weekend of the Games and only just broke even - which was terrible sales for us - everyone thought it would be busy and everyone had a bad weekend. The next weekend was better, when Boris [Johnson] gave another announcement to tell everyone to come back' (questionnaire, 2012).

According to one of the key informants (interviewee 24), such negative experiences were due to 'not understanding how people behave during a Games, so the consequence is that some businesses folded as a result of that'. Another problem which affected footfall and visitation was strict parking restrictions, which discouraged domestic tourists and Londoners from driving to East London. More importantly, however, visitors to Olympic areas were directed to and from sports venues through marshalling and barricades, ensuring dispersion was kept to a minimum:

'Actually we did meet a few people who had got off at Hackney Wick [a creative area adjacent to the Olympic park in Stratford], then they were forced to walk all the way round and down and passed us (...) it was just, it was almost dead around Hackney Wick' (interviewee 14).

\subsection{Missed opportunities and fear}

This diversion of tourists was seen by respondents as a missed opportunity, not only for local organisations but also for the tourists themselves and for local authorities. Tourists missed an opportunity to discover what happens in the artists' studios, 'behind closed doors' (interviewee 13). Local authorities, on the other hand, missed an opportunity to promote the area's creativity: 'they've got like 600 artist studios right on their doorstep [in Hackney Wick], and it's not... you're not taking advantage of it?' (interviewee 14). One such missed opportunity was the decision in 2012 to cancel, for security reasons, the Hackney WickED festival, an open-studio event which normally takes place in July. 
Beside the number of visitors and related footfall, according to research participants an important issue was the actual nature - the quality - of Olympic tourists, who are 'not that interested in art' and 'won't be as enthusiastic as they should be' (interviewee 4). For example:

'If they were interested in buying art from London, it was going to be things like... touristy type things with Union Jacks on, or, or exploring the galleries around... kind of central London' (interviewee 12).

Although most research participants saw the lack of tourists as a missed opportunity, one interviewee suggested that some of the local artists themselves were scared of the 'weird' tourists:

'Lots of the artists thought, "oh my goodness there's going to be thousands of weird people wandering through, and we don't want to be here", so they all went. So, literally it was a ghost town, it was an absolute ghost town' (interviewee 13).

The theme of 'fear' (amongst tourists and event organisers) was prominent in the interviews: fear that the transport system would not cope, fear that visitors would get lost and fear of scruffier areas. According to one interviewee, Olympic tourists were scared of East London:

'Americans and everybody else were terrified of being stabbed (...) they were bussed from the stadiums right into the centre of town' (interviewee 11).

\subsection{Commodification of culture}

A desperate attempt by local authorities to beautify and clean-up arty (and deprived) areas around the Olympic Park ahead of the Games was also mentioned. This included allegedly removing some graffiti drawn by local artists and replacing them with commissioned graffiti made by internationally renowned (non-local) artists (Guardian, 2013). This was seen by some local creative practitioners as symptomatic of the cultural programme curators' inability to appreciate and engage with local talent. The cultural policy consultant interviewed for this research offered a similar view:

'[The cultural programme curators] saw themselves as trying to do something substantially different and of better quality and more international and a lot more contemporary than a lot of the practice they thought they were looking at in East London. (...) Not to take seriously any of the talent that is on their door step, except around the edges and kind of cosmetically, seems to me to be fundamentally misdirected' (interviewee 21 ).

The cultural programme curators' decision to favour internationally renowned artists and larger cultural organisations at the expense of smaller, local ones was associated by many respondents 
with the nature of the Olympic Games. These were variously described as a 'corporate' event, a 'commercial venture', a 'Disneyland' and a branding exercise. The ArcelorMittal Orbit sculpture in the Olympic Park was used by many as an illustration of poor quality art designed by a 'big name' whose only purpose is to attract tourists and media attention. Artists also pointed to the lack of transparency in the cultural projects selection process: 'it's not even through a democratic or a public call process, it's through a privileged network process' (interviewee 11). Some respondents noted the role of sponsors in cultural content curatorship: cultural events were 'tied up and handcuffed' as large corporate sponsors had an impact on the choice of projects to be funded.

\section{DISCUSSION}

Pre-Games government discourse identified small businesses as key potential beneficiaries of London 2012. Opportunity areas described by policy documents included direct procurement opportunities, improved business skills ('fitness to supply') and greater ability to bid for contracts (both in the short and longer term), enhanced image, tourism investment and the development of networks (e.g. DCMS, 2008). These key areas broadly reflect the potential opportunities for creative organisations identified in the literature (Table 1). However, the results described above portray a very different picture. This section discusses the findings of this research and analyses the possible reasons for the overall feeling of disappointment that characterises small creative organisations' perceptions of the impacts of London 2012 and its cultural programme. Policy documents will also be used to identify expectations at government level. Through a literature review, the elusive concept of legacy was unpacked and the specific event impacts that apply to small creative organisations were identified (see Table 1 for an overview). The findings will be therefore discussed based on these potential impacts, with particular focus on positive, longer term impacts. These are most likely to contribute to the development of a legacy, which is generally described as the positive, longer term effect of such an event (IOC, 2013).

Qualitative evidence points to the difficulty of creating a two-way dialogue with local authorities, who were described as keen to provide practical information but less inclined to listen to the needs of small local organisations. This highlights the recurring problem of limited local community consultation being found within the delivery of flagship mega-events (Cashman, 2002). The complexity of Olympic delivery structures, including project organisations and support agencies, also appeared to make the process of identifying useful and relevant information and opportunities difficult for local organisations. This problem was highlighted by a 2013 government legacy report 
claiming that the multiplicity of stakeholders involved had created a 'veritable babble of potentially conflicting voices, the resulting cacophony conflicts with the need for clarity of voice and purpose' (House of Lords, 2013: 23). In this sense, there is little evidence that the Games were at all effective in encouraging first-time relationships between creative community groups and mainstream organisations. On the contrary, the present research provides further evidence that mega-events can often create a culture and practice of marginalising local host communities, thus failing to provide a lasting legacy for them.

Before the Games, policy-makers noted that small firms do not have the 'necessary expertise, experience or structures in place to compete effectively' (London Assembly; 2006: 9). Therefore, leveraging programmes such as networking events, skills development workshops and support for applying for contracts, as well as public meetings to provide information on opportunities, were developed for small organisations ${ }^{3}$.However, our respondents were either unaware of them or did not find them suitable. For example, CompeteFor, an online brokerage service heralded as a major legacy ambition, proved unsuitable for small creative organisations. As noted by respondents, local business organisations that worked as intermediaries, such as East London Business Place, were more effective in delivering opportunities than government organisations (what artists sarcastically referred to as 'officialdom'). Some, such as Create London (which developed precisely because of the Games) still remain and have been described as an example of Olympic legacy (DCMS, 2014).

Research respondents and policy makers (e.g. House of Lords, 2013; London Assembly, 2006) recognised that much of the difficulty experienced by small organisations in applying for Olympicsrelated work arose from the lack of skills and resources (financial and human) needed to comply with formal health and safety and employment standards procedures. This problem is particularly relevant to the creative sector, which is increasingly characterised by micro-businesses and entrepreneurial individuals (Ellmeier, 2003) who prefer the 'creative insecurity' of self-employment to the much less creative insecurity of large corporations (McRobbie, 1999, cited in Ellmeier, 2003). It is therefore fair to ask whether the interest of small creative organisations - albeit heralded as a key growth and tourism development driving force in the East End - was simply de-prioritised or even ever part of the government's vision for the Games. Mitchell et al.'s theory of stakeholder salience (1997) may be used to contextualise their position. Local small creative organisations' legitimacy of claim (derived from their strong presence in East London and central role in public policy) meant their interests and legacy ambitions were listened to in the early planning of the

\footnotetext{
${ }^{3}$ Examples of such initiatives include the 'British Business Club' event programme, supported by an online forum to help UK and overseas business to network, and the 'Springboard for Success' programme, designed to help build contacts and expand, providing a contact database developed for suppliers and buyers (DCMS, 2012)
} 
mega-event, most notably at the bidding stage. However, as the pressure to deliver efficiently, on time and within budget increased, their lack of economic and political power meant their claims were increasingly de-prioritised. This led to a (typically neoliberal) situation whereby opportunities were available but realistically only for firms who had the human and financial resources to seize them (such as internal capacity and bidding know-how). It is in this context, therefore, that the importance of redistributing benefits to stakeholders through more inclusive leveraging strategies (Ziakas, 2014) should be understood.

The Games' failure to afford creative organisations opportunities to capitalise on Olympic symbolism and imagery provides a good example of the discussion above. Notoriously, the IOC imposes extremely strict guidelines on host destinations regarding the use of the Olympic rings and other related imagery. IOC regulations were fulfilled via the Host City Contract, which was subsequently inscribed into UK law through the London 2012 Olympic and Paralympic Act 2006 (for a detailed account of copyright restrictions enforced by the IOC, see Siddons, 2012). These restrictions naturally affect creative organisations the most, as noted by our respondents. To overcome this problem, the Inspire programme ('Inspire mark') was specifically designed to allow small cultural (non-profit) organisations to run events and cultural initiatives in association with London 2012 without having to use copyright-restricted Olympic logos. However, the Inspire programme was highly competitive and poorly communicated, thus failing to provide an inclusive and effective leveraging tool for small and micro creative organisations. Perhaps a stronger, concerted stance against unreasonable IOC regulations would have been more effective, allowing a wider range of grassroots leveraging initiatives such as those described by our interviewees (for instance, pop-up stalls, graffiti, Olympic-themed art exhibitions and prints).

The role of the IOC's copyright restrictions in hindering grassroots leveraging opportunities highlights the primarily commercial nature of the Games and provides evidence of how an Olympic 'striated space' (Deleuze \& Guattari, 1988; McGillivray \& Frew, 2014) is formed. As a matter of fact, Olympic space is controlled, commodified, utilitarian and state-enforced during the Games (from privatisation of public space to sponsor protection), as well as before (e.g., eviction of local residents and businesses) and after (e.g., gentrification). Interestingly, the 'striated' nature of Olympic space also contributed to the lack of tourist footfall during the Games. Amid local security imperatives and high national terrorism threat levels catalysed by the London bomb attacks of 7 July 2005 (one day after the London 2012 bid's success was announced), tourists were carefully channelled from train stations to sports venues, again damaging local cultural organisations and other small businesses in the hospitality and retail sectors. The security actions required to ensure 
safety and regulate the behaviours of large crowds at event sites - a naturalised assumption and key requirement for hosting large events (see Chalkley \& Essex, 1999; Hall, 2006) - must be however recognised. In addition, the 'scruffy' look of the areas around the Olympic Park - whose need for regeneration, ironically, was a key reason why London won the bid to stage the Games - further contributed to the Games organisers' reluctance to let visitors roam and explore.

Before the Games, research participants expressed fears that opportunities linked to the cultural programme might pass them by because most of the available funding would be directed to larger organisations. The tension between creative practitioners and what respondents referred to as 'officialdom' is a recognised characteristic. However, the negative mood in the lead up to the Games (linked to the economic downturn, terrorism threats, and general concerns over practical issues such as transport capacity) may have further discouraged creative organisations from getting involved. In hindsight, the consequences of excessive panic both prior and during the Games should be carefully assessed, and a more effective strategy should be devised to comply with security requirements whilst at the same time avoid alienating event areas from event-related opportunities.

It may seem ironic that one of the few successful leveraging stories from the present research relates to the production of an anti-Cultural Olympiad exhibition and an anti-Olympics poster competition. However, many similar stories of artwork inspired by anti-Olympic feelings exist. A selection of them - including poetry, performative art, video and photography - is collected in a fascinating volume produced and printed in the heart of East London (Powell \& Marrero-Guillamón, 2012). This very well mirrors the antagonistic feeling common amongst our respondents, who criticised the commercial nature of the Olympics. It also confirms the importance of creative resistance in producing small pockets of 'smooth' (non-conformist, subversive) space in the widely regimented and functional Olympic space. As one of our interviewees put it, 'artists live in a world where there are no Olympics... they live in the art world' (interviewee 18). The development of glimmers of 'war machine' (Deleuze \& Guattari, 1988) in response to Olympic regulation and control is important. While any attempt to facilitate this would be counterproductive, there is certainly a need for research to better understand this phenomenon and its impacts on the 'striated space' of the Games.

The tension between selecting projects developed by larger, better known cultural organisations and artists, and privileging local cultural producers regardless of their size is a key issue emerging from this research (particularly in relation to the cultural programme). In the Olympic Park cultural strategy, for example, the Mayor of London took pride in having staged 'the largest cultural festival in the history of the modern Olympic Games, showcasing artists from across the globe alongside the 
UK's finest talent' (LLDC 2014: 3). According to our research participants, cultural curators (including the East London cultural programmer and the curators of the Olympic Park arts programme) did not engage with the local creative community, simply prioritising internationally renowned artists. The marginalisation of local creative organisations highlights the capitalist nature of the Games, whose funding highly depends on the host region's and private sponsors' marketing ambitions. Interestingly, whilst the cultural dimension of the Games has grown substantially over the years, media interest in this aspect has become more fragmented (Inglis, 2008). This has encouraged a form of deep sponsorship (McGuigan, 2005) in which cultural curators prioritise 'big names' in order to attract media attention and satisfy public and private sponsors. Coupled with the diversion of funding discussed above, this phenomenon exemplifies well a wider neoliberal approach of favouring speculative investments - in the form of spectacles - to local service provision (Harvey, 1989a), and a tendency to privatise profits while socialising losses (Peters, 2008).

\section{CONCLUSION}

A major concern raised by this research is how far mega-events can ever realistically incorporate the interests of small local creative communities. The idea that mega-events may systematically disserve the interests of host business communities is a fundamental issue - particularly given that local welfare played a significant role in the initial bidding phases and in the legacy strategy of London 2012. The perception that such mega-events prioritise larger organisations and internationally renowned artists to attract global media attention, combined with the perceived loss of funding, contributed to negative attitudes among our respondents. The four key informants interviewed in 2014, all of which are senior policy makers involved with the Games' planning and delivery - confirmed the creative organisations' views. All noted that host borough small organisations were pumped to prosper from the Games, but they were ultimately unable to access the opportunities projected by some of the policy rhetoric and media hype. This evidence contributes to highlighting the prioritisation by policy makers of (broadly defined) social and economic objectives, regardless of the loss of cultural value which may occur as a result (Foley et al., 2012).

A closer analysis of policy documents reveals an effort by the government and London 2012 delivery organisations to provide support and opportunities for local creative businesses in East London. Initiatives included the Inspire mark and Culture Diary, skills workshops, 'CompeteFor' and networking events. An Olympic Park cultural legacy strategy (LLDC, 2014) was developed to deliver a cultural legacy and help creative organisations maintain their studio space despite 
gentrification. However, this study shows that barriers to opportunities existed. The projected vision that local communities would benefit from the Games, and particularly the importance of creative industries, certainly contrasts with the empirical evidence. This highlights a conflicted relationship between Olympic rhetoric and local reality, supporting critics' view that the rationales for hosting mega-events produced by political elites are no more than legitimising rhetoric (Chalip, 2006).

Problems include inadequate local consultation, redirection of public arts funding to fund the Games, fear of disorders and consequent spatial control, barriers to leveraging, and the idea that local interests appeared to become less of a priority as project deadlines approached. Participants in the study noted that they often felt distant from the project, unable to relate to and often showing signs of antagonism toward what the Olympic [cultural] project was attempting to achieve. Gamesrelated opportunities appear to have been limited, and whilst a small number of local creative practitioners knew how to access opportunities, most respondents did not. This suggests that more localised support, and closer consultation of local needs through existing networks may prove a more effective approach than specific Games initiatives.

Previous research (Stevenson, 2012) highlighted that Olympic park and stadium developments triggered an embryonic form of tourism in Stratford, Hackney Wick and Fish Island (all in East London). Near-by areas such as Shoreditch and Spitalfields already feature well-developed tourism economies and are earmarked as key East London tourism destinations. These areas have many similar characteristics to the areas around the Olympic Park, including a strong creative community, an interesting industrial heritage and a 'scruffy' (bohemian) look. Increasingly, visitors have been attracted to such areas to experience creative, quirky London (Pappalepore et al. 2014). It is therefore plausible that the Olympic Games and related cultural events represented an opportunity to trigger tourism growth and enhance the profile of the local creative industry. By discouraging Olympic tourists from exploring the area, and by cancelling one of the most successful annual local open-studio events, however, local authorities missed a great opportunity. We hope that recent ambitions to promote these creative areas as a cultural quarter, engage local creative organisations in a series of cultural events and ensure that space for artists' studios is preserved (LLDC, 2014) will be fulfilled by the London Legacy Development Corporation without compromising these areas' vibrancy and diversity.

One of the questions guiding the present study was whether any emerging legacies for East London's host community of small creative organisations could be identified. A parallel objective has been to shed light on the concept of legacy from the perspective of a specific stakeholder group. The term legacy, broadly defined as positive, longer-term impacts (IOC, 2013), was unpacked 
through a literature review which identified the key potential impacts of major sporting and cultural events on creative organisations (summarised in Table 1). Such impacts were used as guiding themes to analyse the qualitative data. In this sense, a focus on long-term impacts only would be misguided because short-term positive impacts such as increased visitation and short-term work opportunities - if appropriately leveraged - may eventually lead to longer term impacts such as increased business confidence (Dwyer et al., 2000), improved production organisation (Bergsgard et al., 2010) or increased connection to local audiences (Low \& Hall, 2011). Short- and long-term impacts should be seen as two ends of the same spectrum.

The word legacy - created sixty years ago with a specific purpose, to support an Olympic bid (see Gold \& Gold, 2008, for a full account) - has become increasingly popular in mega-event discourse. The term fits with what Bourdieu and Wacquant (2001) refer to as Newspeak: a new vocabulary resulting from a form of cultural imperialism whereby the realities of a particular society in a particular point in time are 'planetarized' and 'departicularized'. Like other Newspeak words (e.g. governance and employability), legacy 'seems to have sprung out of nowhere, [but] is now on

everyone's lips' (p. 2). In the light of such concerns that legacy remains overly de-contextualised and divorced from reality, we recommend that research must consider legacy in the specific contexts under scrutiny and explore its idiosyncratic and nuanced local dynamics - as attempted by the present study for East London's creative sector.

\section{ACKNOWLEDGEMENTS}

Part of this research was funded by a grant of the International Olympic Committee (IOC).

\section{LIST OF REFERENCES}

Arts Council England [ACE] (2012) Annual review 2012. Available at:

http://www.artscouncil.org.uk/advice-and-guidance/browse-advice-and-guidance/annual-review201112. [Accessed on: 23 October, 2014].

Arts Council England [ACE] (2013) Reflections on the Cultural Olympiad and London 2012 Festival. London: Arts Council England.

Ashton, C (2012) Peking Duck as a museum spectacle: staging local heritage for Olympic tourism, Journal of Tourism and Cultural Change, 2, 150-166. 
BBC (2014) Competition to design Olympicopolis centre in Olympic Park. BBC News Online, 21 July 2014. Available at: http://www.bbc.co.uk/news/uk-england-london-28393906. [Accessed on: 1 August, 2014].

Bergsgard, NA \& Vassenden, A (2011) The legacy of Stavanger as capital of culture in Europe 2008: watershed or puff of wind? International Journal of Cultural Policy, 17 (3), 301-320.

Bergsgard, NA,. Jøsendal K, \& García B (2010) A cultural mega event's impact on innovative capabilities in art production: the results of Stavanger being the European capital of culture in 2008, International Journal of Innovation and Regional Development, 2 (4), 353-371.

Bourdieu, P. \& Wacquant, L (2001) New Liberal Speak: Notes on the New Planetary Vulgate. Radical Philosophy, 105, 2-5.

Burbank, M, Andranovich, G \& Heyying, C (2002) Mega-events, Urban Development and Public Policy. The Review of Policy Research, 19, 179-202.

Cashman, R (2002) Impact of the Games on Olympic host cities [PDF Online]. Available at: http://ceo.uab.cat/lec/pdf/cashman.pdf. [Accessed on: 11 October, 2012].

Chalip, L (2006) Towards Social Leverage of Sport Events. Journal of Sport \& Tourism, 11:2, 109127.

Chalip, L \& Leyns, A (2002) Local business leveraging of a sport event: managing an event for economic benefit. Journal of Sport Management, 16, 132-158.

Chalkley, BS \& Essex, SJ (1999) Urban development through hosting international events: a history of the Olympic Games. Planning Perspectives, 14 (4), 369-394.

Deleuze, G (1995) Negotiations: 1972-1990. New York: Columbia University Press.

Deleuze, G \& Guattari, F (1988) A Thousand Plateaus. London: Athlone Press.

Department for Culture, Media and Sport [DCMS] (1998) Creative Industries Mapping Document. London: DCMS.

Department of Culture, Media and Sport (DCMS) (2007a) Our Promise for 2012: How the UK will benefit from the Olympic Games and Paralympic Games [PDF online]. Available at: https://www.gov.uk/government/uploads/system/uploads/attachment_data/file/77718/Ourpromise20 12Forword.pdf. [Accessed on: 5 January, 2014].

Department for Culture, Media and Sport [DCMS] (2007b) Winning - A tourism strategy for 2012 and beyond. London: DCMS.

Department of Culture, Media and Sport (DCMS) (2008) Before, During and After - Making the Most of the Games [PDF online]. Available at: http://webarchive.nationalarchives.gov.uk/+/http:/www.culture.gov.uk/images/publications/2012Le gacyActionPlan.pdf. [Accessed on: 26 October, 2012]. 
Department of Culture, Media and Sport (DCMS) (2012) Beyond 2012. The London 2012 Legacy story [PDF Online]. Available at:

https://www.gov.uk/government/uploads/system/uploads/attachment_data/file/77993/DCMS_Beyo nd_2012_Legacy_Story.pdf. [Accessed on: 1 September, 2014]

Department of Culture, Media and Sport (DCMS) (2014) Inspired by 2012: The Legacy from the Olympic and Paralympic Games ( $2^{\text {nd }}$ annual report) [PDF Online]. Available at:

https://www.gov.uk/government/uploads/system/uploads/attachment_data/file/335774/140723_Insp ired_by_2012__2nd_annual_legacy_report__accessible.pdf. [Accessed on: 1 August, 2014]

Dwyer, L, Mellor, R, Mistilis, N, \& Mules, T (2000) A framework for assessing "tangible" and "intangible" impacts of events and conventions. Event management, 6(3), 175-189.

Easterby-Smith, M, Thorpe, R, \& Lowe, A (1991) Management Research: An Introduction. London: Sage Publication.

Ellmeier, A (2003) Cultural entrepreneurialism: on the changing relationship between the arts, culture and employment, International Journal of Cultural Policy, 9(1), 3- 16.

European Commission (2005) The new SME definition - User Guide and Model Declaration. Brussels: European Commission.

Fillis, I (2009) Entrepreneurial crafts and the tourism industry, in (Eds.) Ateljevic, J \& Page, S Tourism and entrepreneurship: International perspectives. Oxford: Butterworth-Heinemann. 133149.

Flyvbjerg, B, Bruzelius, N, \& Rothengatter, W (2003) Megaprojects and risk: an anatomy of ambition. Cambridge (UK): Cambridge University Press.

Foley, M McGillivray, D \& McPherson, G (2012) Event Policy: From Theory to Strategy. London: Routledge.

French, SP \& Disher, ME (1997) Atlanta and the Olympics: A One-Year Retrospective. Journal of the American Planning Association, 63, 379-392.

García, B (2004) Urban regeneration, arts programming and major events: Glasgow 1990, Sydney 2000 and Barcelona 2004. International Journal of Cultural Policy, 10 (1), 113-118.

García, B (2008) Sydney 2000. In Gold, J. \& Gold, M. (eds), Olympic Cities. City Agendas, Planning and the World's Games, 1896-2012. Abingdon, UK: Routledge, 287-314.

Gilmore, A (2014) Evaluating legacies: Research, evidence and the regional impact of the Cultural Olympiad. Cultural Trends, 23 (1), 29-41.

Gold, J \& Gold, M (2008) Introduction, In Gold, J. \& Gold, M. (eds), Olympic Cities. City Agendas, Planning and the World's Games, 1896-2012. Abingdon, UK: Routledge, 1-13. 
Gospodini, A (2009) Post-industrial trajectories of Mediterranean European cities: the case of postOlympics Athens. Urban studies, 46(5-6), 1157-1186.

Government Office for London (2007) Supporting communities, preventing social exclusion and tackling need, Available at: http://hamunitedcharities.org.uk/grants/reports/supportingcommunities-preventing-social-exclusion-and-tackling-need/2-background-information-onhammersmith-and-fulham-and-the-targeted-areas-and-wards, [Accessed on: 7 August 2014]

Guardian (2013) Olympic legacy murals met with outrage by London street artists, The Guardian Online, 6 August 2013. Available at:

http://www.theguardian.com/artanddesign/2013/aug/06/olympic-legacy-street-art-graffiti-fury. [Accessed on: 12 October, 2013].

Hall, CM (2006) Urban entrepreneurship, corporate interests and sports mega-events: the thin policies of competitiveness within the hard outcomes of neoliberalism. Sociological Review, 54, 59-70.

Harvey, D (1989a) From Managerialism to Entrepreneurialism: Transformations in Urban Governance in Late Capitalism, Geografiska Annaler, 71B, 3-17.

Harvey, D (1989b) The Condition of Postmodernity. Oxford: Blackwell.

Hiller, H (2002) Toward a Science of Olympic Outcomes: The Urban Legacy, in IOC (2002) (Eds.) The Legacy of the Olympic Games 1984-2000 - International Symposium, Lausanne: IOC, 102-109.

Hiller, H (2006) Post-event Outcomes and the Post-modern Turn: The Olympics and Urban Transformations. European Sport Management Quarterly, 6 (4), 317-332.

House of Lords (2012) The long-term legacy for the UK from the Olympic and Paralympic Games. [PDF Online]. Available at: www.parliament.uk/briefing-papers/LLN-2012-037.pdf. [Accessed on: 15 January, 2014].

House of Lords (2013) Keeping the Flame Alive: the London 2012 Olympic and Paralympic Legacy [PDF Online]. Available at:

http://www.publications.parliament.uk/pa/ld201314/ldselect/ldolympic/78/78.pdf. [Accessed on: 2 January, 2014].

Impacts 08 (2009) Liverpool's Creative Industries: Understanding the Impact of Liverpool European Capital of Culture 2008 on the City Region's Creative Industries. Available at: http://www.liv.ac.uk/impacts08/Publications/Liverpool's_Creative_Industries.pdf. [Accessed on: 30 July, 2014].

Imrie, R \& Thomas, H (1995) Urban Policy Processes and the Politics of Urban Regeneration. International Journal of Urban and Regional Research, 19, 479-494.

Inglis, D (2008) Culture agonistes: social differentiation, cultural policy and Cultural Olympiads. International journal of cultural policy, 14(4), 463-477. 
Institute for Government (2013) Making the Games - What government can learn from London 2012. London: Institute for Government.

IOC (2013) Olympic Games: Legacies and Impacts [PDF Online], Available at: http://www.olympic.org/Assets/OSC\%20Section/pdf/LRes_7E.pdf. [Accessed on: 11 October, 2012].

Jacobs, J (1969) The economy of cities. New York: Vintage.

Kavetsos, G (2012) The Impact of the London Olympics Announcement on Property Prices. Urban Studies, 4 (7), 1453-1470.

Kenyon, J, \& Palmer, C (2008) Funding and Sponsorship: The Commercial Impact of the 2012 London Olympic Games-Some Considerations. Journal of Qualitative Research in Sports Studies, 2(1), 29-44.

KPMG (2014) Tech and creative industries key to Capital's growth. Available at: https://www.kpmg.com/UK/en/IssuesAndInsights/ArticlesPublications/NewsReleases/Pages/techand-creative-industries-key-to-capitals-growth-CBI-KPMG.aspx. [Accessed on: 7 August, 2014].

Legacy Trust (2013) Evaluation Report. Creating a lasting cultural and sporting legacy from the London 2012 Olympic and Paralympic Games. London: Legacy Trust UK.

London Assembly (2006) The Business of the Games: The Opportunities for small and medium sized London firms arising from the 2012 Olympic and Paralympic Games. Economic Development Culture, Sport and Tourism Committee [PDF Online]. Available at: http://www.london.gov.uk/sites/default/files/archives/assembly-reports-econsdolympic_businesses.pdf. [Accessed on: 7 November, 2011].

London Legacy Development Corporation [LLDC] (2014) Arts and Minds, and Dreams, and Tongues - Arts \& Culture Strategy. London: London Legacy Development Corporation.

Low, D \& Hall, P (2011) The 2010 Cultural Olympiad playing for the global or the stage?, International Journal of Cultural Policy, 18 (2), 131-150.

MacRury, I \& Poynter, G (2009) Olympic Cities: 2012 and the Remaking of London. Farnham: Ashgate.

Marrero-Guillamón, I (2013) Olympic state of exception, in (Eds.) Powell, H \& MarreroGuillamón, I (2013) The Art of Dissent. Adventures in London's Olympic State. London: Marshgate. 20-29.

Maxwell, J A (1992). Understanding and validity in qualitative research. Harvard Educational Review 62(3), 279-300.

Mayor of London (2007) Five Legacy Commitments [PDF Online]. Available at: http://legacy.london.gov.uk/mayor/olympics/docs/5-legacy-commitments.pdf. [Accessed on: 12 January, 2014]. 
McGillivray, D \& Frew, M (2014) From Fan Parks to Live Sites: Mega events and the territorialisation of urban space. Urban Studies [published online ahead of print]

McGuigan, J (2005) Neo-liberalism, Culture and Policy. International Journal of Cultural Policy, $11(3), 229-241$.

McKay, M \& Plumb, C (2001) Reaching beyond the gold: the impact of the Olympic Games on real estate markets. Global Insights, 1, 1-28.

McRobbie, A (1999) In the Culture Society: Art, Fashion and Popular Music. London: Routledge.

Mitchell, R K, Agle, B R, \& Wood, D J (1997) Toward a theory of stakeholder identification and salience: Defining the principle of who and what really counts. Academy of management review. 22(4), 853-886.

Molotch, H, \& Treskon, M (2009) Changing art: SoHo, Chelsea and the dynamic geography of galleries in New York City. International Journal of Urban and Regional Research, 33(2), 517541.

O’Brien, D (2006) Event Business Leveraging: The Sydney 2000 Olympic Games. Annals of Tourism Research, 33 (1), 240-261

O'Callaghan, C, \& Linehan, D (2007) Identity, politics and conflict in dockland development in Cork, Ireland: European Capital of Culture 2005. Cities, 24(4), 311-323.

Osmond, M (2002) After the Crowds Have Gone Home. A Case Study Based Assessment of Practical Games Related Legacies for the Sydney Business Community, in (Eds.) IOC (2002) The Legacy of the Olympic Games 1984-2000 - International Symposium. Lausanne: IOC, 237-242.

O'Sullivan, S (2006) Art Encounters Deleuze and Guattari: Thought Beyond Representation, London: Palgrave Macmillan.

Paiola, M (2008) Cultural events as potential drivers of urban regeneration: An empirical illustration. Industry and Innovation, 15, 513-529.

Pappalepore, I, Maitland, R, \& Smith, A (2014) Prosuming creative urban areas. Evidence from East London. Annals of Tourism Research, 44, 227-240.

Peters, M (2008) The Global Failure of Neoliberalism: Privatize Profits; Socialize Losses, Global-e, A Global Studies Journal [Online]. Available at: http://global-ejournal.org/2008/11/06/the-globalfailure-of-neoliberalism-privatize-profits-socialize-losses/ [accessed on 26 June 2015].

Powell, D (2004) Transforming the landscape: culture as the key to winning the Olympics 2012 The Joint Cultural Framework for the Olympic Boroughs [PDF Online]. Available at: http://www.davidpowellresearch.co.uk/documents/TransformingTheLandscape.pdf. [Accessed on: 8 August, 2014].

Powell, H \& Marrero-Guillamón, I (2012) The Art of Dissent. Adventures in London's Olympic State. London: Marshgate. 
Preuss, H (2007) The Conceptualisation and Measurement of Mega Sport Event Legacies. Journal of Sport and Tourism, 12, 207-227.

Raco, M \& Tunney, E (2010) Visibilities and Invisibilities in Urban Development: Small Business Communities and the London Olympics 2012. Urban Studies, 47, 2069-2091

Richards, G (2011) Creativity and tourism. The state of the art. Annals of Tourism Research, 38 (4), $1225-1253$.

Richards, G \& Palmer, R (2010) Eventful Cities: Cultural management and urban regeneration. Routledge: London.

Rifkin, J (2000) The Age of Access: How the Shift from Ownership to Access is Transforming Capitalism. London: Penguin.

Rojek, C (2014) Global Event Management: a critique. Leisure Studies, 33(1), 32-47.

Sacco, PL \& Tavano Blessi, G (2007) European Capitals and Local Development Strategies: Comparing the Genoa and Lille 2004, Homo Oeconomicus, 24 (1),111-141.

Schüßler, E \& Sydow, J (2013) Organizing events for configuring and maintaining creative fields, in (Eds.) Jones C, Lorenzen M and Sapsed J (2013) Oxford Handbook of Creative Industries. Oxford: Oxford University Press.

Siddons, A (2012) London 2012 brand protection - what you need to know, in (Eds.) Powell, H and Marrero-Guillamón, I (2012) The Art of Dissent. Adventures in London's Olympic State. London: Marshgate, 86-99.

Smith, A (2012) Events and Urban Regeneration; the Strategic Use of Events to Revitalise Cities. London: Routledge.

Smith, A (2014) Borrowing' Public Space to Stage Major Events: The Greenwich Park Controversy. Urban Studies, 51(2) 247-263.

Smith, A \& Stevenson, N (2009) A review of tourism policy for the 2012 Olympics, Cultural Trends, 18 (1), 97-102.

Spilling, OR (1996) The entrepreneurial system: On entrepreneurship in the context of a megaevent, Journal of Business Research, 36, 91-103

Stevenson, N (2012) Culture and the 2012 Games: Creating a tourism legacy? Journal of Tourism and Cultural Change, 10 (2), 37-149.

Tomlinson, A (2005) The commercialization of the Olympics: Cities, Corporations and the Olympic commodity, In (Eds.) Young, K and Wamsley, K (2005) Global Olympics: Historical and Sociological Studies of the Modern Games. Oxford: Elsevier.

Vigor, A, Mean, M \& Tims, C (2004) After the Goldrush? A sustainable Olympics for London. London: IPPR/Demos. 
Voluntary Arts (2008) News on the Cultural Olympiad: What will you be inspired to do? [PDF Online]. Available at: http://www.voluntaryarts.org/wp-content/uploads/2012/01/map6991.pdf [Accessed on: 3 August, 2014].

Weber, M (1947) The theory of social and economic organization. New York: Free Press.

Work Foundation (2010) A Lasting Legacy: How can London fully exploit the opportunities created by the Olympic Games in the recover and to 2030? [PDF Online]. Available at:

http://www.theworkfoundation.com/Assets/Docs/olympics011210.pdf. [Accessed on: 11 January, 2014].

Yin R K (2003) Case Study Research. Design and Methods. London: Sage.

Ziakas, V (2014) For the benefit of all? Developing a critical perspective in mega-event leverage. Leisure Studies, (ahead-of-print), 1-14. 